\title{
12. Cleantech venture investors and energy policy risk: an exploratory analysis of regulatory risk management strategies
}

\section{Mary Jean Bürer and Rolf Wüstenhagen ${ }^{1}$}

Venture capital (VC) investments are an important source of financing for innovative entrepreneurial firms. The largest share of VC has traditionally been invested in a few sectors such as information and communication technology (ICT) or biotechnology. More recently, cleantech ventures are attracting increasing amounts of capital, with a particular focus on clean energy technology ventures. VC investments in clean energy can significantly accelerate the market diffusion of climate-friendly technologies such as solar energy or clean biomass. While exhibiting strong growth rates and a surge in media attention in the most recent past (see Figure 12.1), these investments still represent a small percentage of the overall VC market.

In previous research (Wüstenhagen and Teppo, 2006), we identified a number of sector-specific risks as a potential barrier to increasing levels of clean energy VC investments. Given the important role of regulatory drivers for sustainability in the energy sector, it is particularly important for government to understand investors' perceptions of the risks (and opportunities) associated with energy and climate policies and how they manage these risks.

\section{LITERATURE REVIEW}

\section{Regulatory Influences on VC Investments}

Regulatory influences can be identified on various stages of the VC investment value chain (see Figure 12.2).

Traditionally, research on the linkage between government policy and the $\mathrm{VC}$ market has had a relatively narrow perspective on one particular 


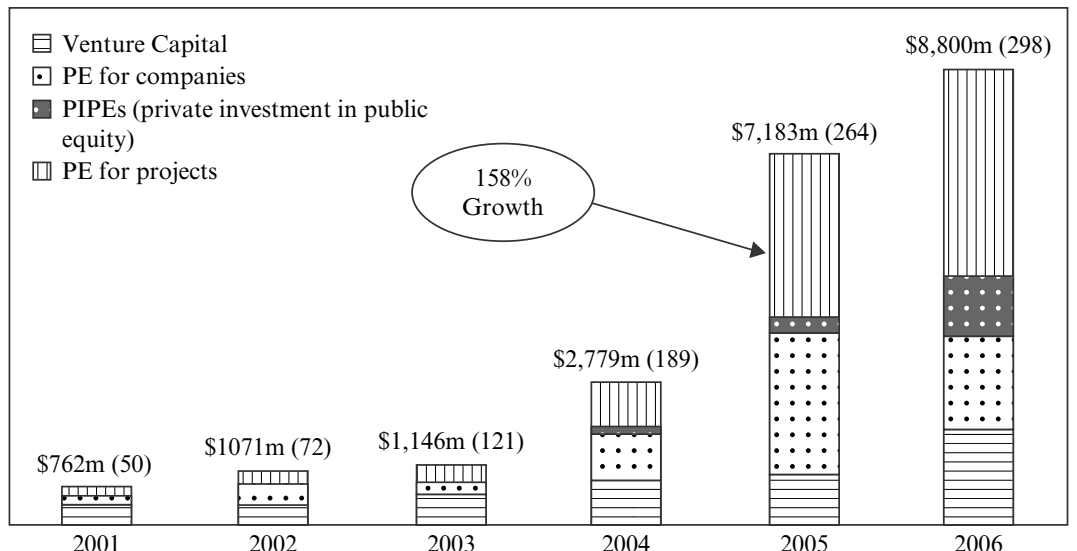

Source: Liebreich (2006).

Figure 12.1 Estimated global clean energy private equity investment. 2001-2006

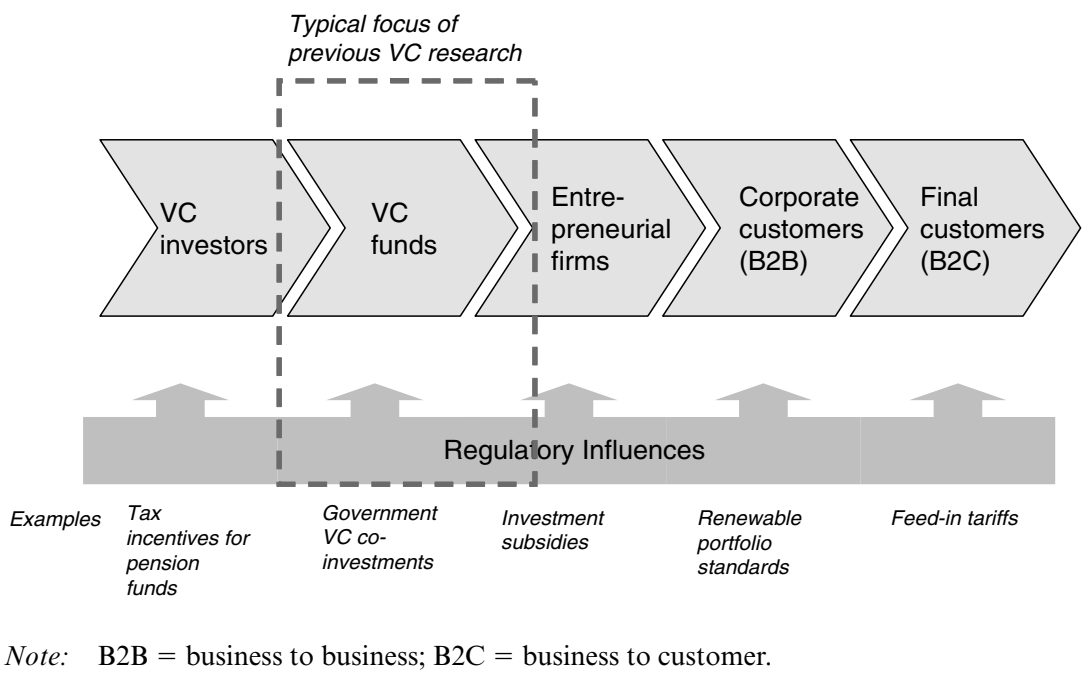

Figure 12.2 Regulatory risk at different stages of the VC investment value chain

stage of the value chain, namely how government can support VC funds (Baygan and Freudenberg, 2000; Jeng and Wells, 2000; Rigau, 2002; Dubocage and Rivaud-Danset, 2004; OECD, 2004). The focus typically is on tax incentives and other forms of direct investment support. The 
2004 OECD report surveyed five policy areas which are conducive to increasing the supply of venture capital: investment regulations, taxation, public equity programmes, business angel networks and second-tier stock markets.

To get a more comprehensive understanding of the links between regulation and the level of $\mathrm{VC}$ investing in a certain sector or country, it is important to also look up and down the value chain. As several authors have noted, the emergence of a healthy VC market requires a whole 'ecosystem' of innovation, which includes sufficient levels of entrepreneurial activity, as well as sufficient capital allocation from investors. Black and Gilson (1998), in their attempt to explain differences in the development of VC markets between the US and other countries, concur that critical institutions, such as experienced venture capitalists and investment bankers experienced in taking early-stage companies public, will not develop quickly. They conclude that a 'strong venture capital market thus reflects an equilibrium of a number of interdependent factors' (p. 272). Kuemmerle (2001), in his comparison of the evolution of VC industries in the US, Germany and Japan, points out that 'an active venture capital industry is arguably ... difficult to create . . . because it typically requires not just a functioning financial system, but a fertile technology system and a climate conducive to entrepreneurship'.

If the emergence of a healthy $\mathrm{VC}$ industry depends on other institutions and actors along the value chain, we can conclude that regulatory policies to support the VC market should also be targeting those players, for example, investors such as pension funds, or entrepreneurial firms as the venture capitalists' 'customers'. An often-quoted best-practice example is the Small Business Innovation Research (SBIR) programme that was designed to assist small technology-based firms to commercialize their products beyond early-stage research and development (R\&D) (US EPA, 1994; Lerner, 1999). This policy has indirectly supported the VC industry by providing funding to early-stage entrepreneurial firms and thereby broadening the universe of investable companies for venture capitalists later on.

Yet even looking at investors, venture capitalists and entrepreneurs will not yet lead to a complete picture of regulatory influences on the $\mathrm{VC}$ market. The success of VC investments ultimately depends on customers' decisions to prefer the entrepreneurial firm's products over existing products. With sustainability innovation being characterized by a strong societal (rather than private) value as described above, regulation is a strong factor influencing demand. Several policies have been developed that influence demand for sustainable energy, such as the UK renewables obligation, where electric utilities are mandated to buy a certain share of their 
power from renewable energy, or the German Electricity Feed-in Law (StrEG), which was introduced in 1991 (Wüstenhagen and Bilharz, 2006). This legislation guaranteed all renewable energy producers a preferred rate for selling the electricity that they generated over 20 years (CEC, 2004). These demand-driven policies have arguably indirectly contributed more to successful VC investments in the German renewable energy sector than many of the measures discussed above that aimed at directly supporting VC funds, and yet they constitute a surprising gap in the literature on regulatory influences on VC.

The view that these policies are indeed important for understanding VC investments in the sustainability sector is underlined by LoGerfo et al. (2005), who find that a number of macro trends will support cleantech as a viable venture investment category for some years to come; for example, local and national policy initiatives such as renewable energy portfolio standards for utilities, subsidies for wind and solar power systems, and 'green building' and environmental procurement requirements for government agencies that create demand for cleantech solutions and kick start the virtuous cycle of 'volume increase cost reduction'. Not much literature exists, however, on the impact of energy and climate policy on the VC industry. One of the few exceptions is an exploratory study by Kasemir et al. (2000) using a policy exercise methodology to survey European venture capitalists' views on climate policies. Among other things, they concluded that European venture capitalists would welcome stricter climate policies on the EU level, even if they were to be introduced unilaterally, as a means to foster innovation in the energy sector and hence support entrepreneurial activity in this sector.

Concluding our review of previous research about regulatory influences on VC investments, while many forms of possible government support for venture capital are being discussed, most of them focus on a relatively narrow stage of the VC value chain. In particular, the one form of government support that is most prevalent in the sustainable energy sector, namely incentives for the venture's final markets, is surprisingly absent in current research. Therefore further research is needed to develop a comprehensive model of regulatory risk in the context of sustainability-related $\mathrm{VC}$ investments.

\section{Perception of Risk and VC Investment Decisions}

Understanding the decision process of venture capitalists, and in particular the relative importance of multiple decision criteria (or risk factors), has been an important theme in $\mathrm{VC}$ research. Early empirical studies by Tyebjee and Bruno (1984) and MacMillan et al. (1987) described the factors that venture capitalists use in assessing an investment opportunity. 
Tyebjee and Bruno summarized their findings in a set of five underlying dimensions that venture capitalists consider (market attractiveness, product differentiation, managerial capabilities, environmental threat resistance and cash-out potential), which they in turn summarized as describing expected return and perceived risk. Riquelme and Rickards (1992), in an exploratory study of 13 venture capitalists, investigated the inherent trade-offs between various factors and their relative importance in the decision process. Muzyka et al. (1996) surveyed 73 European venture capitalists to assess the relative importance of 35 individual criteria, concluding that the leadership potential of the entrepreneur and four other management team criteria (leadership potential of management team, industry expertise, track record of entrepreneur, track record of management team) were consistently of highest importance to European VCs, while product-market and deal-related criteria were less important. They identified three clusters of $\mathrm{VC}$ investors that differed in their perception of the importance of criteria.

While research on $\mathrm{VC}$ decision has traditionally followed a rationalist paradigm, recent contributions are increasingly shifting towards a behavioural paradigm and point to the importance of perceptional factors. The importance of behavioural aspects was first highlighted by Amos Tversky and Daniel Kahneman (1974) who demonstrated that decisions under uncertainty exhibit significant deviations from the rationality assumptions in conventional economic and financial theory. They showed that such decisions are governed by intuition more than reasoning (Kahneman, 2003) and are characterized by a number of cognitive biases (McFadden, 2001) such as anchoring-and-adjustment, availability and status quo biases (Samuelson and Zeckhauser, 1988). In sum, a significant effect of these biases is that they lead to conservatism in adjusting to new information (Tversky and Kahneman, 1974; Kahneman, 2003). In another important contribution, Kahneman and Tversky (1979) drew attention to anomalies in choices under risky prospects, demonstrating that losses are weighted differently from gains, and that expected losses and gains, rather than final assets, explain investor behaviour. This marked the starting-point of research in behavioural finance which analyses investment decisions that are based on heuristics and biases. Empirical evidence for the theoretical phenomena described by Kahneman and Tversky and the stream of behavioural economic research built on their insights has been found in various areas, including investor behaviour in stock markets (Lakonishok et al., 1994; Jordan and Kaas, 2002; Chan and Lakonishok, 2004), currency speculation (Bikhchandani et al., 1992; Froot et al., 1992; Bikchandani and Sharma, 2001), and managerial decision making (McNamara and Bromiley, 1999). More recently, scholars in entrepreneurship and VC research have taken up 
the theme (for example, special issue of the Journal of Business Venturing (2004) on cognitive perspectives in entrepreneurship research; Levesque and Schade, 2005). In the context of venture capital, Shepherd (1999) and Zacharakis and Shepherd (2001) found evidence for overconfidence and availability bias among a set of Australian and US venture capitalists, respectively, and Shepherd et al. (2003) indicated that decision accuracy of venture capitalists as a function of their experience appeared to decrease, rather than increase beyond a certain point. Lange et al. (2004) investigated cultural influences on the perception of venture risk attributes and the consequent willingness to invest in family businesses. They found some early indications that there are in fact differences in mental definitions and perceptions of risk among specific investor groups. Baum and Silverman (2004) investigated Canadian biotechnology venture capitalists and concluded that they tend to overemphasize human capital-related factors for the success of new ventures, and pointed to the need for further research on cognitive biases in VC investment decisions. In a survey of German venture capitalists by Weber and Dierkes (2002), 44 per cent of venture capitalists stated that 'personal chemistry' is very important for their investment decision.

While insightful in many respects to extend $\mathrm{VC}$ research beyond narrow rationality assumptions, none of these studies has explicitly focused on the perception of regulatory risk by venture capitalists, partly because sustainability-related VC investments are a relatively recent empirical phenomenon and this aspect may be less prevalent in other sectors. A particular insight from previous research is that it points to cultural and experience effects, which can cause venture capitalists to deviate from what would be purely rational investment behaviour. With regulatory risk being subject to many uncertainties and cultural interpretations, one might expect to see interesting evidence for such biases in the area of clean energy VC investments.

\section{Venture Capitalists' Risk Management Strategies}

As VC investing is a risky undertaking in many respects, a good part of the literature deals with risk management strategies. A distinction can be made between two fundamental options, namely 'actively managing risks', and 'passively diversifying risk'.

With regard to actively managing risks, there is extensive literature about how venture capitalists manage the inherent risks of their investments, mainly focusing on the risks resulting from principal-agent problems between the venture capitalist and the entrepreneur (see, for example, Kaplan and Strömberg, 2001a, 2001b; Hellmann, 2004). Gompers (1995) maintains that three risk management mechanisms are common to almost all VC investments: (i) the use of financial contracting (most commonly by 
financing through convertible securities), (ii) syndication of investment, and (iii) staged financing. Since regulatory risk is not rooted in the venture capitalist-entrepreneur relationship, but rather in the business-government relationship, one may question whether there is scope for active risk management at all. However, there is some evidence that active regulatory risk management is not foreign to VC practitioners. Consider, for example, the statement of this venture capitalist quoted in Wüstenhagen and Teppo (2006: 73): 'VCs need to have competence in lobbying if they want to succeed in the energy sector, just like the big American mainstream [venture capitalists] have their guys in Washington DC'.

This quotation demonstrates that actively managing risks must take different forms when it comes to regulatory risk. Venture capitalists may manage these risks either on an individual firm level or by taking collective action (also referred to as 'structural political action of firms' by Schneidewind, 1998, or as 'policy development strategies' by Dyllick et al., 1997) to influence the regulatory framework for some or all of their portfolio companies. While the idea of actively managing regulatory risk is relatively well established in the corporate sustainability literature, it is largely neglected in $\mathrm{VC}$ research.

Portfolio diversification (also referred to as 'passive risk management' in the finance literature) is another important aspect of managing risk. Smolarski et al. (2005) point out that VC portfolio theories and management have not received significant attention in the literature and are not well understood. This can be explained by the fact that portfolio theories have traditionally been developed in public equity markets where stocks can be bought and sold every day, and risk and return data can be determined on a daily basis. For VC investments, in contrast, investments are illiquid over several years, and short-term returns and prices are nonobservable. While there are periodic revaluations of $\mathrm{VC}$ and private equity holdings, these are often subjective. Traditional measures of risk may therefore be inappropriate for measuring risk and return of $\mathrm{VC}$ investments (Chiampou and Kallett, 1989). Looking at regulatory risk from a portfolio diversification perspective is somewhat unusual, since political or regulatory frameworks are often considered to be non-diversifiable (or systematic) risks, while the term 'diversifiable' (or unsystematic) risk is more frequently associated with firm-internal aspects (because they can be diversified away by investing in a portfolio of companies). At the same time, in a sector such as clean energy, where regulatory drivers are ubiquitous, it may be worthwhile to look at the regulatory framework as a form of diversifiable risk and think about diversification strategies. Finally, diversification of regulatory risk may apply not only to a venture capitalist's portfolio as a whole, but also to a single portfolio company if it 
manages to diversify its business activities across international markets (and hence get exposure to different regulatory environments).

\section{DATA AND METHODS}

The purpose of our research project was to develop a robust model of regulatory risk management strategies applied by cleantech VC investors. To reach this exploratory objective and develop theory that is empirically grounded, an inductive approach is most appropriate (Glaser and Strauss, 1967; Eisenhardt, 1989; Yin, 1994).

Based on a review of the existing literature and a preliminary understanding of the research context, we designed an interview guideline that we applied in three forms, namely telephone interviews, an online questionnaire ${ }^{2}$ and an abbreviated paper-and-pencil version of that online questionnaire, all directed at $\mathrm{VC}$ and private equity (PE) investors with an exposure to the clean energy technology sector. Our empirical data collection took place between October 2006 and April 2007. Online surveys were mostly undertaken between January 2007 and February 2007. Survey respondents were principals or investment managers in $\mathrm{VC}$ and private equity funds. In the full version of the questionnaire, 30 questions were asked about (i) the fund's investments in clean energy, (ii) preferences with regard to various energy and innovation policies, and (iii) regulatory risk management strategies. In the surveys and interviews, information was also collected on a number of basic characteristics of the funds, management practices and skills, as well as clean energy views and preferences. Investors were asked about major drivers for clean energy investment, hindering factors for more clean energy investment, their investment criteria for clean energy deals, their typical time to exit for clean energy deals, various fund characteristics (size of clean energy funding, size of all VC or PE funding, fund type, firm type and so on), and various factors which are relevant to how they manage their funds. For example, funds were asked about their most influential sources of information, how much exposure and interaction they tend to have with policy makers and portfolio companies, what backgrounds their investment teams tend to have and so on. Other policy perception questions were about international climate policy, nuclear energy and clean energy industry regulatory issues. Perceptions on policy were generally based on a 5 -scale rating. Depending on their availability and preferences, the respondents replied to the questionnaire either online, in written form, or in an interview. Interviews allowed for further qualitative information to be gathered, such as the investors' views on why the clean energy sector has attracted so much interest in recent years. However, in some cases interviewees did not 
have enough time to complete the full interview and only a subset of questions were asked of them in such cases. Participant observation at two major international industry conferences of cleantech venture capitalists and web searches of fund websites complemented our data collection. The respondents to the interviews and surveys had been assured of 100 per cent confidentiality in the reporting of the results.

The sample is considered to be representative of the general investment actors in the $\mathrm{VC}$ and private equity investment space in the clean energy sector. Further details about the various characteristics of the sample of funds used for the empirical data analysis are discussed in Bürer (2007).

The survey was first sent to 200 investment companies in the private equity field which were located around the world, but mostly in Europe. Emails were directed to the managing director or a similarly senior position in each company. It was later estimated that about 100 of the funds reached were effectively involved or interested in the clean energy sector. Therefore, a more focused list of these 100 funds was used in a second electronic mailing to invite participants to utilize the online software to complete the survey. A thorough research of relevant people at each fund was conducted in order to increase the response rate among this set. Initially, the response rate was not high enough after this mailing, so follow-up emails were sent to select groups of investors which were considered to be the most important players in the field. In some cases, the fund managers who were contacted were invited to participate in a quick interview of 10-15 minutes only, in order to increase the response rate among this busy and important set of funds. Although the data have been compiled via three different methods and with varying completeness, in this manner it was possible to reach a response rate of approximately 60 per cent among the funds which were deemed to be the most important players in the field. Considering the time availability of venture capitalists for academic research of this type, this can be considered to be a relatively high overall response rate. Sixty fund managers from Europe and North America took part in the survey, of which 80 per cent had already invested in a clean energy deal. Out of the 60 fund managers, about one-third completed the web-based questionnaire, another third returned the shorter paper-and-pencil version and another third responded either face to face or via the telephone. However, not all questions were answered by all respondents. For example, only 30 out of the 60 participating firms answered the question on regulatory risk management in the questionnaire, because only those participating in the longer survey or interviews could answer these questions.

Finally, in order to understand what drives investors to invest in clean energy today, it was also considered of interest to interview a number of investors in the clean energy field that were not in the category of VC and PE 
fund managers. Therefore, a few additional interviews were conducted to supplement the qualitative research in this chapter with the following types of investors: (i) institutional investors who invest in clean energy funds (one pension fund, three banks, and one fund of fund), (ii) project financiers (three PE investors for projects in the clean energy sector), and finally (iii) a few advisory firms in the PE and VC space for clean energy technology ventures.

\section{REGULATORY RISK MANAGEMENT STRATEGIES OF CLEAN ENERGY VENTURE INVESTORS}

Based on our findings from the interviews and surveys, we developed the conceptual model of regulatory risk management strategies shown in Figure 12.3. We find that investors use both active and passive risk management strategies. The results demonstrated that 22 fund managers had an active risk management strategy as their primary approach, while eight had a passive (diversification) strategy. For active risk management strategies, we distinguish inbound and outbound risk management, where inbound means strengthening a venture's policy expertise by hiring people with relevant expertise, and outbound means actively influencing the regulatory environment. Thirteen of the 22 fund managers in the active category had an inbound approach, as their primary approach. As for passive risk management strategies, we distinguish diversification on the portfolio (or fund)

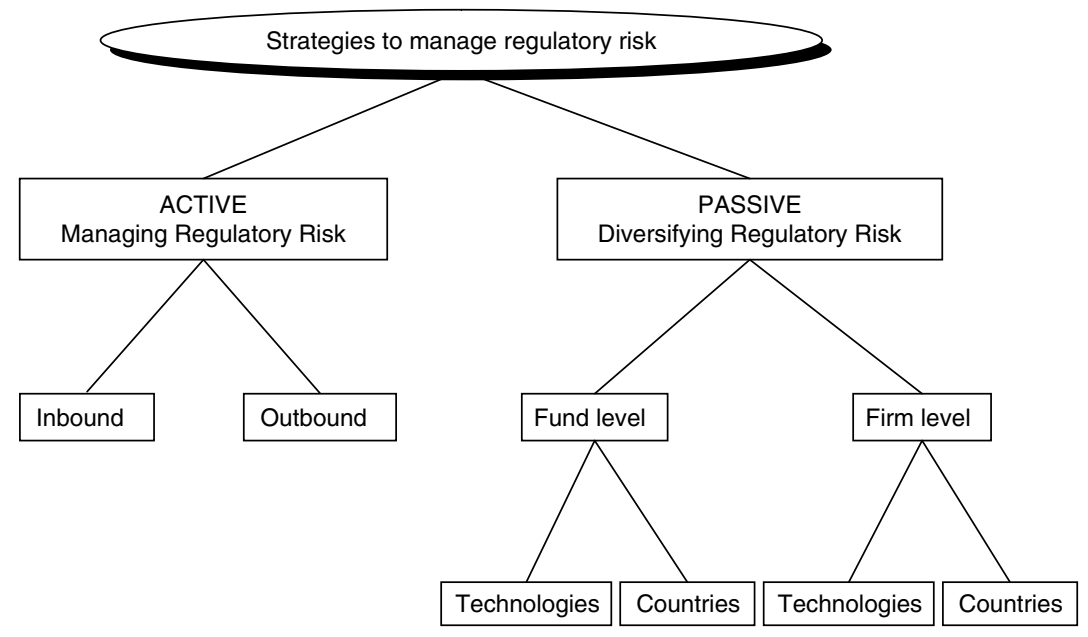

Figure 12.3 Typology of venture investors' regulatory risk management strategies 
level and on the firm level, as well as diversification across technologies and across countries. Of this category, the strategies primarily used by respondents were quite evenly divided among fund- and firm-level diversification approaches. Some fund managers applied two strategies or more in parallel. We shall elaborate more on each of these strategies below, and illustrate them with direct quotations from our interviews and survey responses.

\section{Active Regulatory Risk Management Strategies}

\section{Active risk management, inbound}

The rationale behind the first form of actively managing regulatory risk is to strengthen the ties with relevant policy makers and increase the capacity of the firm to react quickly to newly emerging regulatory opportunities and challenges by recruiting people with specialized policy skills. This may include setting up a dedicated function for regulatory affairs management, or - more likely in an earlier stage of the company - giving board seats to people with a strong policy background:

We create a strong advisory board for the portfolio company, preferably with leads into the large corporates and utilities in the energy space. (Venture capitalist C12)

The key is being aware of and responding to policy drivers. (Venture capitalist D09)

\section{Active risk management, outbound}

The second form of actively managing regulatory risk is in a sense even more proactive, in that the $\mathrm{VC}$ fund actively gets involved in the regulatory process and tries to influence decision making in the policy arena in a way that benefits its portfolio companies:

We have several people working in groups that are involved in defining new regulations. We actively manage regulatory risks. We are politically active as investors. We ask for harmonization of the most effective policies in Europe. (Venture capitalist D05)

Also, one partner [in our fund] is involved in a political party. (Venture capitalist D12)

Regulatory risk - we try to . . influence the policy development getting as much information as we can and also talking to the regulators themselves. We meet twice a year with policy makers in the countries we invest in. (Venture capitalist D08)

In the context of this approach of active, outbound regulatory risk management, we asked how often investors actually meet with policy makers. 


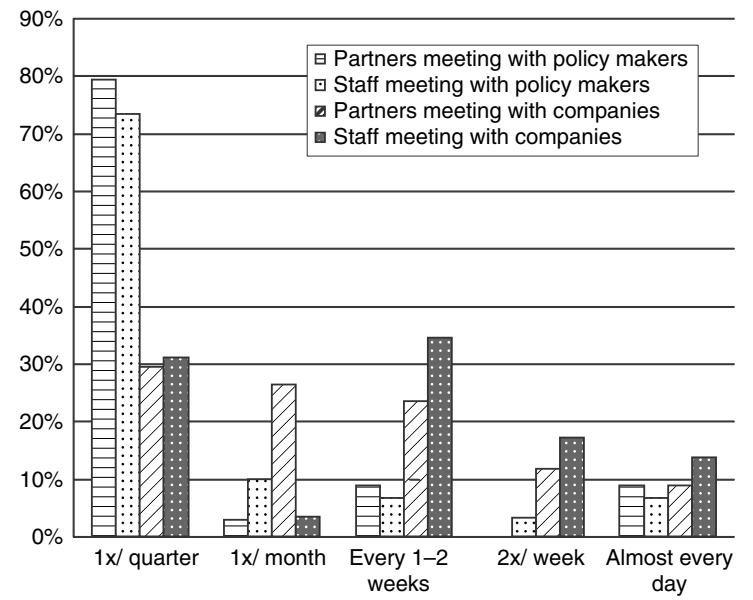

Figure 12.4 Frequency of direct interactions between venture capitalists and policy makers versus portfolio companies $(\mathrm{N}=30)$

Figure 12.4 shows the results of this question, and uses the frequency of interaction with the portfolio firms for comparison (see also Appendix 12A). It turns out that most venture capitalists have rather rare direct interactions (including meetings at industry conferences) with policy makers. About three-quarters of them meet with policy makers once a quarter or less. On the other end of the spectrum, almost 10 per cent of investors indicated that they interact with policy makers more than once a week or even almost every day. An interesting finding with regard to these results is that the one type of fund which meets with policy makers more often than they meet with portfolio companies are funds that invest in late-stage clean energy deals.

\section{Diversification - Passive Regulatory Risk Management Strategies}

\section{Fund level, across technology}

As for passive risk management strategies (or diversification), the first option is to deal with regulatory risk on the fund level and invest in a portfolio of companies that represent different technology segments. An example may be to invest in several clean energy technologies, including solar, wind, biomass and fuel cells, which differ in the way that they are dependent on policy support:

Our portfolio companies are active ... in different areas and technologies, so this reduces the regulatory risk. (Venture capitalist D01) 
While there seemed to be widespread support for the idea of diversifying portfolios across technologies among the funds that we interviewed, there were also some exceptions, that is, funds that were focusing on just a small subset of clean energy technologies. However, these more focused funds acknowledged the inherent higher level of (regulatory) risk that they were taking:

Our fund concentrates on solar and wind. We make big bets because our investors want us to take the risks. (Venture capitalist C09)

\section{Fund level, across countries}

Another approach to diversification of regulatory risk is to invest in a portfolio of ventures in different countries. As clean energy policies still differ significantly from country to country, and also the timing of legislative decisions with regard to, for example, introducing or changing renewable energy support policies varies, having a portfolio of companies acting in different jurisdictions is a good hedge for regulatory risk:

You can follow policy making from Japan to California and that goes back to the team and initial investment. You might have 3-4 countries where you are betting on $\mathrm{CO}_{2}$ emissions policy in Europe and the United States (e.g., California). (Venture capitalist C11)

Our portfolio companies are active in different countries . . . so this reduces the regulatory risk. (Venture capitalist D01)

\section{Firm level, across technology}

A similar distinction with regard to diversification across technologies versus countries can be made on the firm level. Of these two options, diversification across technologies on the firm level is more rare, especially in the case of early-stage ventures that tend to be focused on a single technology. In a later stage of firm development, diversification across technologies does become a possibility, for example in the case of photovoltaics companies acquiring solar thermal energy businesses, or wind energy project developers moving into biomass projects.

\section{Firm level, across countries}

The more common form of diversification on the firm level is cross-country diversification, or internationalization:

Unless you are very comfortable about a particular legislation, you would probably shy away from investing in a company that is $100 \%$ dependent on policy in one country. (Venture capitalist D01) 
Again, internationalization will typically occur in a later stage of company development. However, there are also examples of very early internationalization, as for example in the case of the VC-backed wave energy company Ocean Power Delivery, headquartered in Scotland, but selling first commercial products to Portugal due to the more favourable policy environment.

\section{Further Observations on Regulatory Risk Management Strategies}

\section{Adaptation to policy changes}

Interview partners highlighted the fact that a particularly important dimension of regulatory risk with regard to clean energy VC investments is the risk of changes in policy. While anticipating (or even preventing) policy changes may often be beyond a fund's (or firm's) control, investors pointed out that some firms may be better positioned than others to cope with these risks. Especially in the case of solar energy, which currently has high policy support levels in Germany, but where changes to this regulation might raise challenges to the financial performance of German solar companies, the ability of a firm's management to adapt to these changes may be very important:

We can manage the policy, but we can't manage the changes in policy. . . Also you need to have confidence in the venture's management team (that they can make the necessary changes in the company if policy changes). (Venture capitalist C11)

This is the approach assuming that the regulatory risk will change over the period of time you are investing (e.g., it may change much less in the first year, but in years $2-5$ you don't know how it will change). If the management team lowers cost, increasing efficiency in the technology (e.g., solar), you can win despite changes in regulatory issues. (Venture capitalist D06)

\section{Relative importance of regulatory drivers versus market drivers}

Another important aspect of regulatory risk management, particularly with regard to clean energies where demand for a venture's product is often driven by government incentives or regulations, is to find the right balance between government-driven demand and 'voluntary' customer demand. In other words, investors can manage regulatory risk by selecting firms whose product has a clear path to consumer adoption and whose success is therefore not 100 per cent dependent on policy:

As for regulatory risk management, you hopefully made an investment where the policy is additive, but not the totality of what you are betting on. (Venture capitalist C11)

Our investments do not rely on subsidy supports, or at least they rely very little on them. (Venture capitalist D11) 


\section{CONCLUSIONS}

Government policies affect venture capital investment at various stages of the VC value chain. Previous literature has mainly focused on direct policies aimed at increasing the amount of capital available to venture capitalists in a particular country, or altering the risk-return equation for investors by, for example, providing tax incentives for venture capitalists. Our findings suggest that regulatory influences on VC investments are more multifaceted, and include policies that influence VC investors indirectly, for example by creating attractive markets for VC-backed companies. We also show that the relationship between regulation and $\mathrm{VC}$ investments is not a one-way street as the literature on government $\mathrm{VC}$ policies tends to suggest. Rather, we demonstrate that venture capitalists can (and do) also influence policies, and that there are ways for them to manage regulatory risk.

Our findings extend the literature on VC decision making by highlighting the importance of regulation as a risk factor in assessing investment opportunities. Much of the previous VC literature focuses on traditional forms of investment risk such as market and technology risks and neglects regulatory risk as a factor seemingly outside the scope of VC influence. Especially for a sector with obvious political influence as in the case of the energy industry, this narrow view on investment risk neglects important risk factors, but may also lead to missed opportunities. Our findings also link to the emerging discussion in entrepreneurship and VC literature about rationalist versus behavioural perspectives on decision making, in that we highlight the striking differences in venture capitalists' perceptions of regulatory risk. Energy policies that some actors seem to be seeing as a risk are perceived as an opportunity by others.

Our research makes an important contribution to the literature of risk management strategies by developing a conceptual framework for strategies of VC investors to manage regulatory risk. We distinguish active strategies for managing regulatory risk from passive ways of diversifying regulatory risk. Active risk management strategies can take two forms, inbound and outbound. Passive strategies can be applied at firm or at portfolio level, and diversification can be achieved across technologies or across countries. Apart from this conceptual contribution, we also demonstrate empirically that clean energy venture investors actually apply a range of different strategies at the same time to manage regulatory risk, from among the various forms of active and passive risk management that we discussed. Our typology of regulatory risk management strategies sheds light on the diversity of approaches, and allows for a systematic categorization of those strategies.

In a broader sense, this chapter contributes to the literature on non-market strategies of companies by extending the perspective from corporate political 
activity of large incumbent firms to the interplay between policy and small entrepreneurial firms. It also highlights the role that investors in those firms, particularly venture capitalists, play in mediating the firm-policy relationship.

\section{LIMITATIONS AND FURTHER RESEARCH}

The conceptual model developed from our exploratory research is based on a limited number of qualitative interviews with venture capitalists. Further research with a larger sample can help to assess the relative importance of the identified strategies. Investors were also the main source of information for our categorization of regulatory risk management strategies on the firm level. Surveying the management teams of entrepreneurial firms would be a valuable extension of our research and could help to add to the venture's perspective. Finally, a selected number of longitudinal case studies may be useful to assess the success of certain regulatory risk management strategies in coping with unexpected changes in the policy environment.

\section{NOTES}

1. The authors acknowledge funding from the Research Fund of the University of St. Gallen, project no. G12221104. The research presented in this chapter has also benefited from earlier work of the same authors in a project funded by the Swiss Federal Office of Energy under contract no. 151652.

2. For a full version of the survey instrument, see Bürer (2007, Annex 1).

\section{REFERENCES}

Baum, J.A.C. and Silverman, B.S. (2004), 'Picking winners or building them? Alliance, intellectual, and human capital as selection criteria in venture financing and performance of biotechnology startups', Journal of Business Venturing, 19, 411-36.

Baygan, G. and Freudenberg, M. (2000), 'The internationalisation of venture capital activity in OECD countries: implications for measurement and policy', OECD Science, Technology and Industry Working Papers, 2000/7, doi:10.1787/ 084236411045.

Bikhchandani, S., Hirshleifer, D. and Welch, I. (1992), 'A theory of fads, fashions, customs and cultural change as informational cascades', Journal of Political Economy, 100, 992-1026.

Bikhchandani, S. and Sharma, S. (2001), 'Herd behavior in financial markets', IMF Staff Papers, 47 (3).

Black, B.S. and Gilson, R.J. (1998), 'Venture capital and the structure of capital markets: banks versus stock markets', Journal of Financial Economics, 47, 243-77. 
Bürer, M.J. (2007), 'Public policy and clean energy private equity investment', University of St. Gallen: PhD dissertation (forthcoming).

CEC (2004), Status Report 2004: Energy End-use Efficiency and Electricity from Biomass, Wind and Photovoltaics and in The European Union, August; Authors: Paolo Bertoldi, Thomas Huld, Niina Kautto, Harald Scholz, Ewan Dunlop, Arnulf Jäger-Waldau, Andrew Machirant, Marcel Suri; Editor: Arnulf Jäger-Waldau.

Chan, L.K.C. and Lakonishok, J. (2004), 'Value and growth investing: review and update', Financial Analysts Journal, 60 (1), 71-86.

Chiampou, G.F. and Kallett, J.L. (1989), 'Risk/return profile of venture capital', Journal of Business Venturing, 4, 1-10.

Dubocage, E. and Rivaud-Danset, D. (2004), 'The development of venture capital in Europe: the role of public policy', in Capital Market Development and the Economy, Tokyo Club Papers, No. 16, 76-117, Tokyo Club Foundation for Global Studies, www.tcf.or.jp/data/20021203-04_Frederique_Sachwald_ Dorothee_Rivaud-Danset.pdf.

Dyllick, T., Belz, F. and Schneidewind, U. (1997), Ökologie und Wettbewerbsfähigkeit (Environment and Competitiveness), Munich/Vienna: Carl Hanser and Zurich: Verlag Neue Zürcher Zeitung.

Eisenhardt, K.M. (1989), 'Building theories from case study research', Academy of Management Review, 14 (4), 532-50.

Froot, K., Scharfstein, D. and Stein, J. (1992), 'Herd on the street: informational efficiencies in a market with short-term speculation', Journal of Finance, 47, $1461-84$.

Glaser, B.G. and Strauss, A.L. (1967), The Discovery of Grounded Theory, Chicago: Aldine.

Gompers, P. (1995), 'Optimal investment, monitoring and the staging of venture capital', Journal of Finance, 50, 1461-89.

Hellmann, T. (2004), 'IPOs, acquisitions and the use of convertible securities in venture capital', Working paper 1702, Stanford Graduate School of Business, January, http://strategy.sauder.ubc.ca/hellmann/pdfs/xit04.pdf.

Jeng, L.A. and Wells, P.C. (2000), 'The determinants of venture capital funding: evidence across countries', Journal of Corporate Finance, 6, 241-89.

Jordan, J. and Kaas, K.P. (2002), 'Advertising in the mutual fund business: the role of judgmental heuristics in private investors' evaluation of risk and return', Journal of Financial Services Marketing, 7 (2), 129-40.

Kahneman, D. (2003), 'Maps of bounded rationality: psychology for behavioral economics', American Economic Review, 93 (5), 1449-75.

Kahneman, D. and Tversky, A. (1979), 'Prospect theory: an analysis of decisions under risk', Econometrica, 47 (2), 263-91.

Kaplan, S. and Strömberg, P. (2001a), 'Venture capitalists as principals: contracting, screening, and monitoring', American Economic Review, 91, 426-30.

Kaplan, S. and Strömberg, P. (2001b), 'Financial contracting theory meets the real world: an empirical analysis of venture capital contracts', Working paper, University of Chicago, September.

Kasemir, B., Toth, F. and Masing, V. (2000), 'Climate policy, venture capital, and European integration', Journal of Common Market Studies, 38 (5), 891-903.

Kuemmerle, W. (2001), 'Comparing catalysts of change: evolution and institutional differences in the venture capital industries in the U.S., Japan and Germany', in Chesbrough, H. and Burgelman, R.A. (eds), Comparative Studies of Technological Evolution, Vol. 7, Amsterdam: Elsevier, 227-61. 
Lakonishok, J., Shleifer, A. and Vishny, R.W. (1994), 'Contrarian investment, extrapolation, and risk', Journal of Finance, 49 (5), 1541-78.

Lange, J., Leleux, B. and Muzyka, D. (2004), 'New ventures and attitudes to risk: a multi-country empirical analysis', in Zahra, S. et al. (eds), Frontiers of Entrepreneurship Research 2004, Proceedings of the Twenty-Fourth Annual Entrepreneurship Research Conference, Babson Park, MA: Babson College.

Lerner, J. (1999), 'The government as venture capitalist: the long-run impact of the SBIR program', Journal of Business, 72 (3), 285-318.

Levesque, M. and Schade, C. (2005), 'Intuitive optimizing: experimental findings on time allocation decisions with newly formed ventures', Journal of Business Venturing, 20, 313-42.

Liebreich, M. (2006), 'European energy investment trends', presentation at the European Energy Venture Fair, 11 September, Rüschlikon, Zurich (Switzerland), www.energyvcfair.com/download_06/session1_michael_liebreich.pdf.

LoGerfo, J., Parker, N. and Propper de Callejon, D. (2005), Cleantech Venture Investing: Patterns and Performance, March, Cleantech Venture Network LLC, http://cleantechnetwork.com/Publications/CleantechPatternsandPerformanceFl yer.pdf.

MacMillan, I.C., Zemann, L. and Subba Narasimha, P.N. (1987), 'Criteria distinguishing successful from unsuccessful ventures in the venture screening process', Journal of Business Venturing, 2 (2), 123-38.

McFadden, D. (2001), 'Economic choices', American Economic Review, 91 (3), 351-78.

McNamara, G. and Bromiley, P. (1999), 'Risk and return in organization decision making', Academy of Management Journal, 42 (3), 330-39.

Muzyka, D., Birley, S. and Leleux, B. (1996), 'Trade-offs in the investment decisions of European venture capitalists', Journal of Business Venturing, 11, 273-87.

OECD (2004), 'Venture capital: trends and policy recommendations', Synthesis paper of country peer reviews on venture capital to analyse recent market trends and the policy framework in selected OECD countries, as part of the OECD project on Growth Follow-up: Micro-Policies for Growth and Productivity.

Rigau, A. (2002), 'The development of venture capital fundraising in Europe. Evidence across countries, prospects and policy issues', thesis for European Economic Studies, Economic Department, College of Europe, Bruges.

Riquelme, H. and Rickards, T. (1992), 'Hybrid conjoint analysis: an estimation probe in new venture decisions', Journal of Business Venturing, 7 (6), 505-18.

Samuelson, W. and Zeckhauser, R. (1988), 'Status quo bias in decision making', Journal of Risk and Uncertainty, 1 (1), 7-59.

Schneidewind, U. (1998), Die Unternehmung als strukturpolitischer Akteur (Firms as political actors), Marburg: Metropolis.

Shepherd, D.A. (1999), 'Venture capitalists' assessment of new venture survival', Management Science, 45 (5), 621-32.

Shepherd, D.A., Zacharakis, A. and Baron, R.A. (2003), 'VCs' decision processes: evidence suggesting more experience may not always be better', Journal of Business Venturing, 18, 381-401.

Smolarski, J., Verick, H., Foxen, S. and Kut, C. (2005), 'Risk management in indian venture capital and private equity firms: a comparative study', Thunderbird International Business Review, 47 (4), July-August, 469-88.

Tyebjee, T.T. and Bruno, A.V. (1984), 'A model of venture capitalist investment activity', Management Science, 30 (9), 1051-66. 
US EPA (1994), Bridging The Valley of Death: Financing Technology for a Sustainable Future, Prepared by the US Small Business Administration for the US Environmental Protection Agency, December.

Weber, C. and Dierkes, M. (2002), Risikokapitalgeber in Deutschland Strukturmerkmale, Entscheidungskriterien, Selbstverständnis (Venture Capitalists in Germany - Characteristics, Decision Criteria, Self-Image), Berlin: edition sigma.

Wüstenhagen, R. and Bilharz, M. (2006), 'Green energy market development in Germany: effective public policy and emerging customer demand', Energy Policy, 34, 1681-96.

Wüstenhagen, R. and Teppo, T. (2006), 'Do venture capitalists really invest in good industries? Risk-return perceptions and path dependence in the emerging European energy VC market', International Journal of Technology Management, $34(1 / 2), 63-87$.

Yin, R. (1994), Case Study Research: Design and Methods, 2nd edn, Beverly Hills, CA: Sage.

Zacharakis, A.L. and Shepherd, D.A. (2001), 'The nature of information and overconfidence on venture capitalists' decision making', Journal of Business Venturing, 16, 311-32. 


\section{APPENDIX 12A SAMPLE QUESTION FROM THE QUESTIONNAIRE (BASIS FOR FIGURE 12.4)}

Question 19: How often does your firm interact with the following?

\begin{tabular}{lcccccc}
\hline & $\begin{array}{c}1 \times 1 \\
\text { quarter, } \\
\text { or less }\end{array}$ & $\begin{array}{c}\text { About } 1 \times 1 \\
\text { month }\end{array}$ & $\begin{array}{c}\text { Every 1-2 } \\
\text { weeks }\end{array}$ & $\begin{array}{c}2 \times \text { a } \\
\text { week }\end{array}$ & $\begin{array}{c}\text { Almost } \\
\text { every day }\end{array}$ & N/A \\
\hline $\begin{array}{c}\text { Partners meeting } \\
\text { with policy makers }\end{array}$ & $\mathrm{O}$ & $\mathrm{O}$ & $\mathrm{O}$ & $\mathrm{O}$ & $\mathrm{O}$ & $\mathrm{O}$ \\
$\begin{array}{c}\text { Staff meeting with } \\
\text { policy makers }\end{array}$ & $\mathrm{O}$ & $\mathrm{O}$ & $\mathrm{O}$ & $\mathrm{O}$ & $\mathrm{O}$ & $\mathrm{O}$ \\
$\begin{array}{c}\text { Partners meeting } \\
\text { with typical } \\
\text { clean energy }\end{array}$ & $\mathrm{O}$ & $\mathrm{O}$ & $\mathrm{O}$ & $\mathrm{O}$ & $\mathrm{O}$ & $\mathrm{O}$ \\
$\begin{array}{c}\text { company } \\
\begin{array}{l}\text { Staff meeting } \\
\text { with typical } \\
\text { clean energy }\end{array}\end{array}$ & $\mathrm{O}$ & $\mathrm{O}$ & $\mathrm{O}$ & $\mathrm{O}$ & $\mathrm{O}$ & $\mathrm{O}$ \\
company & & & & & & \\
\hline
\end{tabular}

